\title{
Anthropogenic hydrometeorological changes at a regional scale: observed irrigation-precipitation feedback (1979-2015) in Nebraska, USA
}

\author{
Jozsef Szilagyi ${ }^{1,2}$ (1) $\cdot$ Trenton E. Franz ${ }^{3}$
}

Received: 12 November 2018 / Accepted: 11 January 2020 / Published online: 23 January 2020

(c) The Author(s) 2020

\begin{abstract}
Long-term tendencies in annual, seasonal, and monthly (March) precipitation, evapotranspiration, and air- and dew-point temperature values were correlated with county-level changes in irrigated area across Nebraska over the 1979-2015 period. A statistically significant linear relationship (slope of $-1.65 \pm 0.33 \mathrm{~mm}$ decade ${ }^{-1}$ per $\%$ decadal change in irrigated area, with a correlation coefficient of -0.47) was found between the trends in annual precipitation and irrigated land area. Precipitation dropped by $1 \mathrm{~mm}$ annually if the level in irrigation expansion reached about $8 \%$ per decade, while the rest of the state enjoyed about a half-millimeter overall increase in annual precipitation rates. The drop was not evenly distributed within the year: the largest decrease took place in the spring, followed by autumn, while the winter and summer months experienced a slight precipitation increase independent of land use. In contrast to what was reported for Eastern Africa by Alter et al. (Nat Geosci 8:763-767. https://doi.org/10.1038/ngeo2514, 2015), the evaporation-enhanced colder land surface of the irrigated fields stabilizes the overlying atmosphere most effectively not in the summer months when precipitation is most abundant in Nebraska, but rather in early spring and fall. The observed precipitation suppression of irrigation only works at the regional scale; it does not apply to irrigated land that is not an integral part of the more-or-less continuous irrigated land region of east-central Nebraska.
\end{abstract}

Keywords Large-scale irrigation $\cdot$ Land-atmosphere feedbacks $\cdot$ Land-use change $\cdot$ Climate change

\section{Introduction}

Irrigated agriculture represents $20 \%$ of the global cultivated land area, but contributes $40 \%$ of the total worldwide food production (FAO 2016). The Asian continent with its 2.3 million $\mathrm{km}^{2}$ of irrigated land is responsible for roughly $70 \%$ of the irrigation area worldwide. Almost $60 \%$ of these 2.3 million $\mathrm{km}^{2}$ - or $42 \%$ of the world total-is located in only two countries, China $\left(0.7\right.$ million $\left.\mathrm{km}^{2}\right)$ and India

Jozsef Szilagyi

jszilagyi1@unl.edu

1 Department of Hydraulic and Water Resources Engineering, Budapest University of Technology and Economics, Budapest, Hungary

2 Conservation and Survey Division, School of Natural Resources, University of Nebraska-Lincoln, Lincoln, NE, USA

3 School of Natural Resources, University of Nebraska-Lincoln, Lincoln, NE, USA
(0.67 million $\mathrm{km}^{2}$ ) where also almost $40 \%$ of the world population is found (FAO 2016). The United States with its 0.26 million $\mathrm{km}^{2}$ is the third on the list. Large-scale longsustained irrigation has led to several environmental problems, such as salinization ( 0.37 million $\mathrm{km}^{2}$ worldwide), groundwater-level and streamflow reductions, seawater intrusion in coastal regions, and the dramatic shrinking and breaking up of the Aral Sea into several disconnected water bodies in Central Asia (FAO 2016) with its entailing public health and environmental disaster (Waehler and Dietrichs 2017). Due to the ongoing climate change and the resulting increased variability in weather extremes (such as flooding and droughts, often in the same area and year), a still growing worldwide population will depend even more strongly on large-scale irrigation developments which raises the issue of long-term sustainability. From all the different potential dimensions (energy and water-use efficiency, productivity, and water quality), this study is about to focus on the most unexpected and least trivial one: the suppression of local precipitation by large-scale irrigation. 

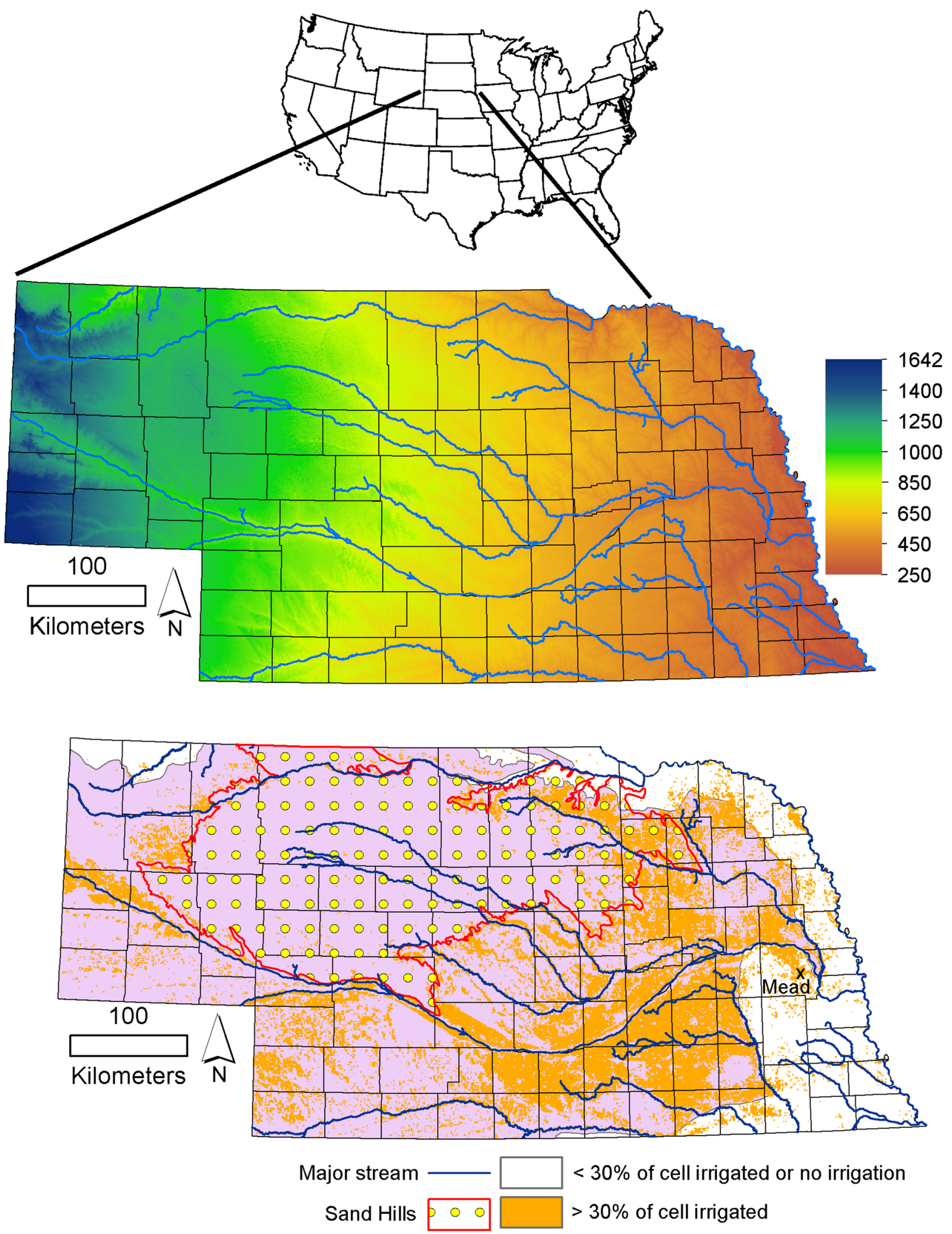

High Plains aquifer 
४Fig. 1 Surface elevation (m) and irrigated land [after Brown and Pervez (2014)] distribution in Nebraska around 2012. The cells are about $1 \mathrm{~km}^{2}$ in area. The straight lines are county boundaries. Location (Mead, NE, USA) of the soil moisture data is also marked

In a recent paper, Szilagyi (2018a) demonstrated the effect of large-scale irrigation to the regional hydrologic cycle in Nebraska, the state that boasts the largest irrigated land area within the United States (Johnson et al. 2011). It was shown that under a $2.4 \mathrm{~mm}$ decade ${ }^{-1}$ state-wide annual precipitation $(P)$ increase during the 1979-2015 period, annual streamflow rates dropped by $-2.8 \mathrm{~mm}$ decade $^{-1}$ due to an estimated $5.5 \mathrm{~mm}$ decade $^{-1}$ increase in annual evapotranspiration (ET) rates caused mainly by an about $50 \%$ increase in irrigated land area from $\sim 23,000 \mathrm{~km}^{2}$ in 1978 to about $34,000 \mathrm{~km}^{2}$ in 2012 (USDA 2012), the last year of official records (Fig. 1). It was also found that annual ET rates on average increased by about $7 \mathrm{~mm}$ decade $^{-1}$ over the irrigated fields (mainly maize and soybean) of east-central Nebraska accompanied by a simultaneous $-4.4 \mathrm{~mm} \mathrm{decade}{ }^{-1}$ drop in annual precipitation rates, while a similar ET rate increase of $6 \mathrm{~mm}$ decade $^{-1}$ in the Sand Hills of Nebraska (Fig. 1), where irrigation is virtually absent, required an $8.1 \mathrm{~mm}$ decade $^{-1}$ increase in annual $P$, in accordance with expectations, since higher precipitation rates should result in higher runoff (i.e., streamflow) in general. From the spatial overlap of the regionally significant expanse of irrigated land and that of dropping precipitation rates, Szilagyi (2018a) concluded that the multi-decadal continuous expansion of irrigation in Nebraska may have led to the observed suppression in precipitation rates.

Similar findings were reported by Alter et al. (2015) for the Gezira irrigation development in central Sudan, Eastern Africa, where irrigated land area grew from 1000 to about $9000 \mathrm{~km}^{2}$ over an 80 year period causing a roughly $50 \mathrm{~mm}$ reduction in July precipitation rates over the irrigated fields in comparison with non-irrigated areas. Zeng et al. (2017) in Northern India also found a 40-50 mm difference in modeled summer (June, July, and August) precipitation sums over a 40-year period between irrigated areas of progressive groundwater extraction (from 85 to $130 \mathrm{~mm} \mathrm{year}^{-1}$ ) and the control rain-fed area.

The consequences of the somewhat contra-intuitive irrigation expansion versus precipitation suppression feedback mechanism are significant, because the enhanced moisture transport that originates in these irrigated fields (under dropping precipitation rates) leads to increased precipitation and streamflow rates (Harding and Snyder 2012; Huber et al. 2014; Wei et al. 2013; Pei et al. 2016) downwind, potentially as far as Illinois and Indiana (over a possible distance of a thousand $\mathrm{km}$ ) within the US (DeAngelis et al. 2010; Kustu et al. 2011). This large-distance boost of water-vapor transport combined with dropping local precipitation is significant from a water resources sustainability (both surface and subsurface) viewpoint (Gleick 2003), as well as from a climate modeling and climate modification perspective (Puma and Cook 2010; Mahmood et al. 2010, 2014; Pielke et al. 2011). With increasing recognition, regionally significant irrigated areas are especially challenging for incorporation into regional and global climate models that commonly employ a Land Surface Model (LSM) component for deriving surface fluxes of sensible and latent heat (Best et al. 2015). This is so because the LSMs aim to maintain a continuous water balance of the soil layers (e.g., Mesinger et al. 2006) to which precipitation and irrigation water fluxes are both input variables, the rate of the latter being typically unknown, as most farmers around the world are not required to meter their water use (Gleick 2003; Hanak et al. 2011). The problem may be alleviated by the application of latent heat flux estimation methods that do not need information of precipitation/irrigation nor any land surface, soil, vegetation, land-use or land-cover variables/ parameters, and also are calibration-free, such as the one (i.e., Szilagyi et al. 2017) that was employed in this study, and previously provided long-term US-wide monthly ET rates (Szilagyi 2018b) requiring only commonly available atmospheric (air-, dew-point temperature, and wind speed) and net surface radiation data. Such ET estimates may prove to be helpful with the calibration, verification, parameterization, and even with anticipated future upgrade of the existing LSMs. These improved LSMs then may lead to better modeling of the long-term effects of largescale irrigation on the regional- and global-scale water resources and climate itself.

The aim of the present study is to provide further support for the large-scale irrigation expansion versus precipitation suppression feedback mechanism, as was first proposed by Szilagyi (2018a) for Nebraska, unaware of the above studies with similar findings. By doing so, one may also gain a better insight of the mechanics involved which then may lead to improved modeling of the inherent physical processes, the latter proving especially important, since, as of today, none of the available atmospheric models (Harding and Snyder 2012; Huber et al. 2014; Pei et al. 2016) capture the observed precipitation suppression accurately, if at all. The present approach is unique to previous ones in that irrigation expansion data are not only quasi-continuous (reported every 5 years over a period in excess of 30 years), but it is also spatially resolved at least on a county level (Fig. 1), unlike the much spottier (temporally irregular irrigation survey data with an average increment of 15 years) and spatially lumped Sudan data (Alter et al. 2015), or the model-derived-only Northern India results (Zeng et al. 2017) with no easy verification by measurements. 


\section{Study area and data employed}

Around $93 \%$ of Nebraska's total land area $\left(200,356 \mathrm{~km}^{2}\right)$ is farm and ranchland in almost equal parts. Half of the range- and pastureland is found in the Sand Hills (Fig. 1). $44 \%$ of the farmland is irrigated by a total amount of almost a hundred-thousand registered and active irrigation wells supplying water to the $34,000 \mathrm{~km}^{2}$ of harvested cropland and pasture (NDA 2019). Irrigated land area by county in Nebraska was obtained from the United States Department of Agriculture census data (USDA 2012) for the 1978-2012 period (Fig. 2).

Monthly precipitation $(P)$, and air- $\left(T_{\mathrm{a}}\right)$ and dew-point $\left(T_{\mathrm{d}}\right)$ temperature data were collected from the Precipitation on Independent Slopes Model (PRISM, Daly et al. 1994) database. Monthly ET rates came from the complementary relationship (CR) derived (Szilagyi et al. 2017; Szilagyi 2018b) $4.2-\mathrm{km}$ resolution ET estimates available across the conterminous United States for 1979-2015. For additional information on ET modeling and spatial distribution of the variables and their linear trends within Nebraska, see Szilagyi (2018a).

Moderate Resolution Imaging Spectroradiometer (MODIS) mean monthly (May-October) daytime surface temperature data were also employed over the 2000-2009 time period for illustration of the state-wide irrigationenhanced surface-cooling effect of evaporation. Cold season months (November-April) were not available because of significant cloud contamination problems that exist in the MODIS images for the given geographic location during that time of the year. Finally, volumetric soil moisture data (plots \#2 and \#3 of irrigated and rain-fed soybean and maize rotations) from a depth of $10 \mathrm{~cm}$ at Mead, in eastern Nebraska (Fig. 1), were obtained from the AMERIFLUX network for further illustration of the effect of irrigation on land surface moisture in March when cloud contamination-free MODIS data are rarely available on a monthly basis for Nebraska. See Verma et al. (2005) for more detail about soil moisture measurements and site description of the Eastern Nebraska Research and Extension Center (ENREC) near Mead, NE.

\section{Methodology}

Decadal changes in irrigated land area were derived on a county basis from linear tendencies of the countywide irrigated areas over the available 1978-2012 period (Fig. 2) and assumed valid also for 1979-2015. These tendencies were then correlated with similar county-wide tendencies in PRISM $P, T_{\mathrm{a}}, T_{\mathrm{d}}$, and CR-ET values. The correlation of the county-wide linear trend in irrigated area and the same linear trend in the chosen variable was performed on an annual (including the ET/P evaporation ratio), seasonal, and monthly (for March) bases. For each relationship sought for, a second-order polynomial was fit over the data to allow for nonlinearities in the relationship. A linear correlation coefficient value was calculated only when the relationship found was clearly linear. As it turned out such was a rare occurrence (it happened only for the trend in annual precipitation), thus a two-sided $t$ test was employed at the typical 5\% significance level and with the unequal variance option (as most of the data typically display diminished variance with the level of irrigation development) to check for a statistically significant change in the value of the variable among two groups of data: the 30 counties with the smallest and another 30 with the highest level of change in irrigation development. The results of the test are included in the corresponding figure captions. Typically, those counties that already had a high irrigation level (i.e., irrigated land area relative to county area) in 1979 produced also the largest change in irrigated area over the study period (Johnson et al. 2011), expressed by the 0.68 value of the linear correlation coefficient between these two variables.

A note on terminology The words ET and evaporation are used in a mutually interchangeable way in the text. In both cases, they refer to land surface evaporation which typically contains a transpirational component, however, subdued for the winter months and for cropland between harvesting and sprouting.

\section{Results and discussion}

Counties with the largest concentration of irrigated land in 1979 are mainly found in east-central Nebraska (Fig. 2). These are the counties that also produced the largest growth in general in irrigated area (see also Johnson et al. 2011) over the 1979-2015 period. The spatial overlap of irrigation expansion versus concurrent precipitation decline is clearly noticeable in Fig. 2. Out of the three counties that suffered the largest decline in precipitation (i.e., white color), two also produced (dark blue) significant gains in irrigated area, while the third neighbors directly with such rapidly developing counties. The relationship is better seen in Fig. 3 that captures well the dramatic precipitation decline with irrigation development. While counties with the weakest irrigation development enjoyed an about $5 \mathrm{~mm}$ decade $^{-1}$ gain in annual precipitation, the ones with the strongest development lost twice that much, about $-10 \mathrm{~mm} \mathrm{decade}^{-1}$ in the same period. The relationship has a linear correlation coefficient of -0.47 and a slope of $-1.65 \pm 0.33 \mathrm{~mm}$ dec$\operatorname{ade}^{-1}$ for every percent of decadal change in irrigated area. 
Fig. 2 Extent of irrigation (1979) in Nebraska by county (altogether 93), as well as decadal changes in irrigated land area and annual precipitation between 1979 and 2015
Irrigated area (\%) in 1979 relative to county area

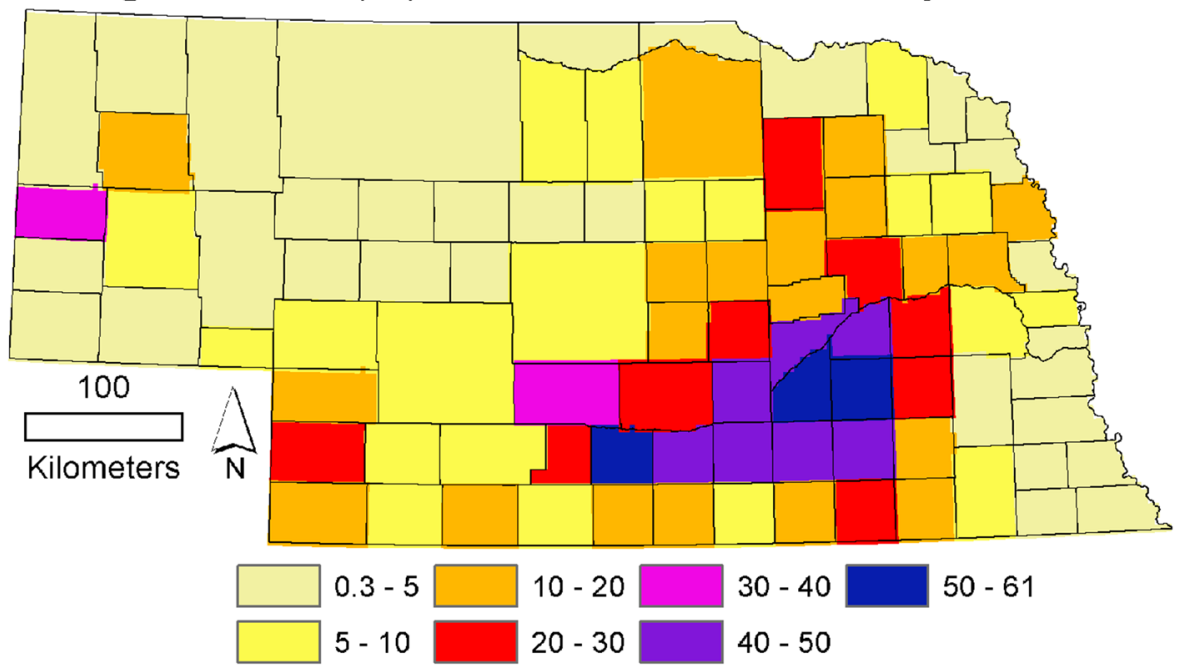

Decadal change (\%) in irrigated area since 1979

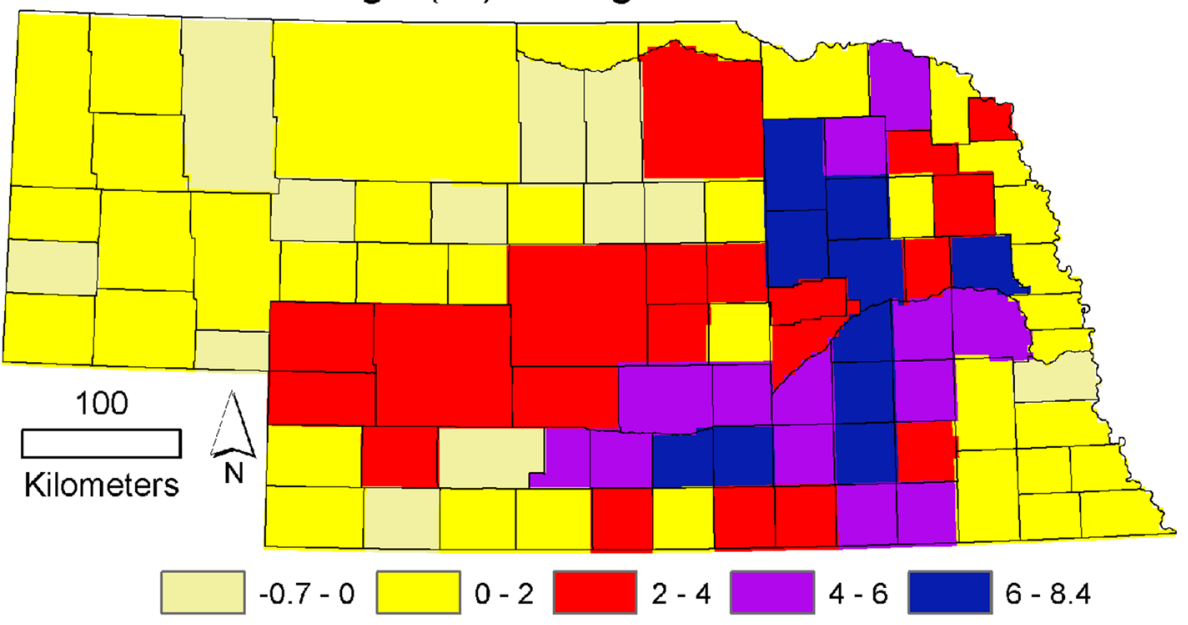

Decadal change (\%) in annual precipitation since 1979

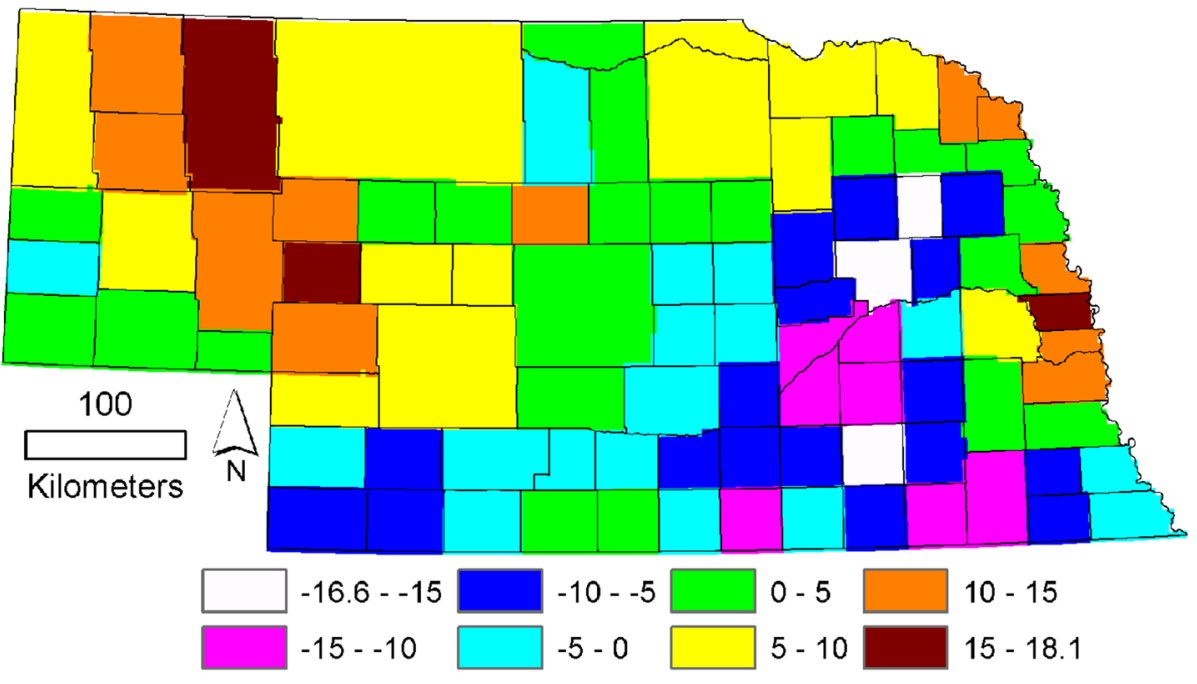


Fig. 3 Decadal changes (1979-2015) in annual precipitation, ET, ET ratio, and air- $\left(T_{\mathrm{a}}\right)$ and dew-point temperature $\left(T_{\mathrm{d}}\right)$ values versus change in county-level irrigated land area in Nebraska. The intermittent lines are the best-fit second-order polynomials. The differences in the mean of the variables for the first (smallest or negative change in irrigated area) and last (largest expansion in irrigation) 30 counties are all statistically significant at the $5 \%$ level, except for $T_{\mathrm{d}}$
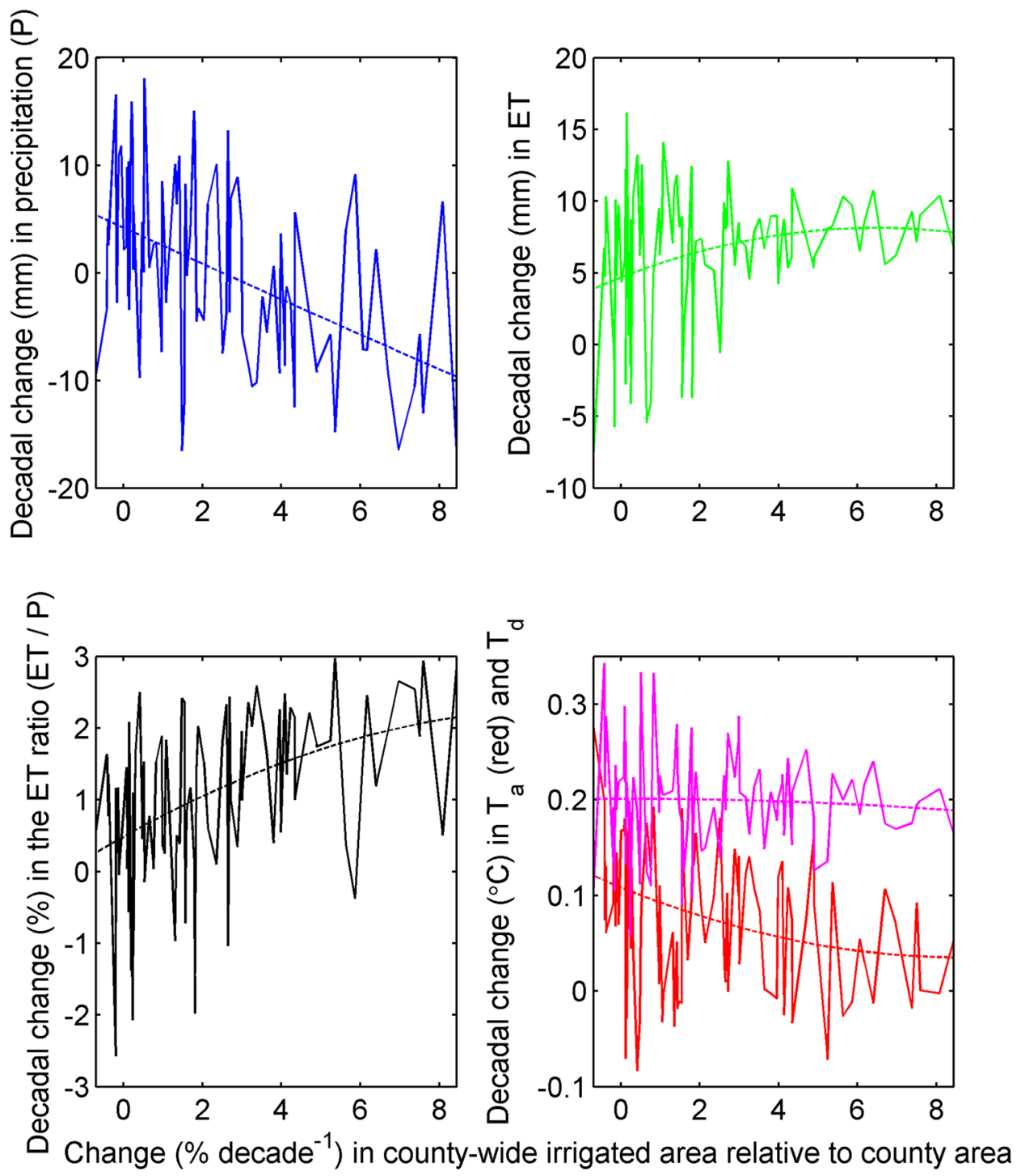

The trend/slope is significant at any customary significance level $\left(p=1.67 \times 10^{-7}\right)$ of the Mann-Kendall linear trend test, modified for possible autocorrelations in the data (Hamed and Rao 1998). The precipitation data also fail the two-sample $t$ test (with the uneven variance option) of equal means $\left(p=7 \times 10^{-7}\right)$ taken from the first (i.e., least irrigation development) and last (most development) 30 data points in the graph.

The effect of irrigation development is significant also on ET rates $(p=0.017)$, the ET ratio (i.e. ET $\left.P^{-1}, p=9 \times 10^{-6}\right)$, and air temperature $\left(T_{\mathrm{a}}, p=0.0046\right)$; the latter demonstrating the strong cooling effect of irrigation-boosted evaporation on the land surface and the air. While counties in Nebraska with the least or shrinking irrigation development warmed at a rate of about $0.1{ }^{\circ} \mathrm{C}$ per decade during 1979-2015, the most irrigated ones did so only at the third of that rate. Irrigation expansion seemingly did not have an effect on the dew-point temperature $(p=0.63)$ which increased by double the rate of air temperature. However, the source of this increase is different between non-irrigated and irrigated land: for the former, air humidity mainly increased due to the observed precipitation (and the subsequent ET) increase, while for the latter, the source of this increase is almost entirely irrigation-enhanced evaporation. Note that air temperature in itself can only boost ET rates on a long-term basis if there is an additional source of water to rain-supplied soil moisture coming from reduced runoff and/or recharge to the groundwater or the groundwater itself for shallow soils that can replenish the exhausted soil moisture from below, driven by higher temperatures and, therefore, potentially higher ET rates.

The standard explanation of precipitation suppression by irrigation (e.g., Alter et al. 2015) is the decrease in air temperature (Fig. 3) due to the enhanced latent heat requirement of the irrigation-boosted evaporation which leads to less buoyancy of the cooler air which then radially flows 
outward over the surface of the colder irrigated area and, therefore, creates an atmospheric subsidence with clockwise surface wind anomalies (very similar to anticyclones) in the northern hemisphere which then reduces precipitation over the irrigated area and enhances it downwind, up to several hundreds of kilometers (DeAngelis et al. 2010; Kustu et al. 2011; Alter et al. 2015). From this explanation, the largest precipitation suppression should occur (Alter et al. 2015) in the summer months, when irrigation, and therefore, surface cooling is the strongest in Nebraska, but available data exhibit more complexity than that. As demonstrated in Fig. 4, the largest precipitation suppression takes place in the spring and autumn, and not in the summer when precipitation does not express a clear correlation with irrigation development, even though $T_{\mathrm{a}}\left(p=1.7 \times 10^{-6}\right)$ and ET rates $\left(p=5 \times 10^{-4}\right)$ do.

The best possible explanation is probably given by Harding and Snyder (2012) who-from numerical modeling of the atmosphere above the Great Plains of the US-found that the increasing convective available potential energy stemming from the irrigation-enhanced low-level moisture typically overwhelms the simultaneous surface-cooling boosted inhibition of vertical convections, thus yielding a net local gain, or at least avoiding a loss, in precipitation. Another possible explanation by the present authors can be that in the summer, the atmosphere is more chaotic due to higher net energy available at the surface, thus more able to destroy any subtle local circulation patterns, such as the one Alter et al. (2015) describe as necessary for precipitation suppression. This latter explanation allows larger convective available potential energy win in the summer months and lose in spring and autumn to surface-cooling boosted (see Fig. 5) inhibition of vertical convections when this potential energy is weaker. Figure 4 supports this hypothesis, since in autumn, the atmosphere over Nebraska is more stable, with only 19.1 precipitation days compared to 28.2 such days in the summer (with an average $8.5 \mathrm{~mm}$ precipitation per rainy days versus $6.3 \mathrm{~mm}$ in the fall). As a result, precipitation suppression
Fig. 4 Changes (1979-2015) in seasonal precipitation $(P)$, ET, and air- $\left(T_{\mathrm{a}}\right)$ and dew-point temperature $\left(T_{\mathrm{d}}\right)$ values versus change in county-level irrigated land area in Nebraska. The intermittent lines are the best-fit second-order polynomials. The differences in the mean of the variables for the first (smallest or negative change in irrigated area) and last (largest expansion in irrigation) 30 counties are statistically significant at the 5\% level for the $P$ values in spring, for the ET and $T_{\mathrm{a}}$ values in summer, and for all variables in autumn

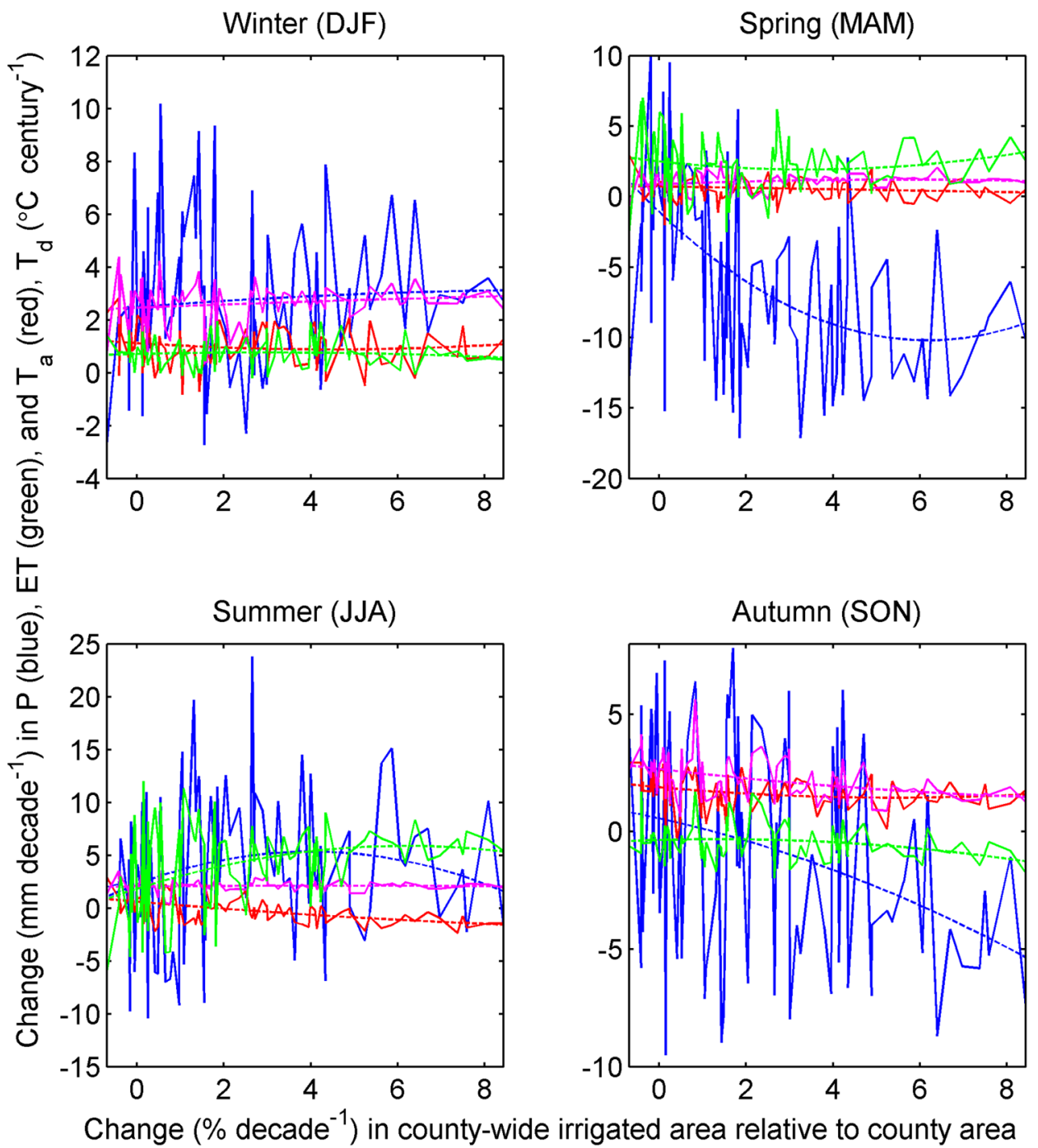



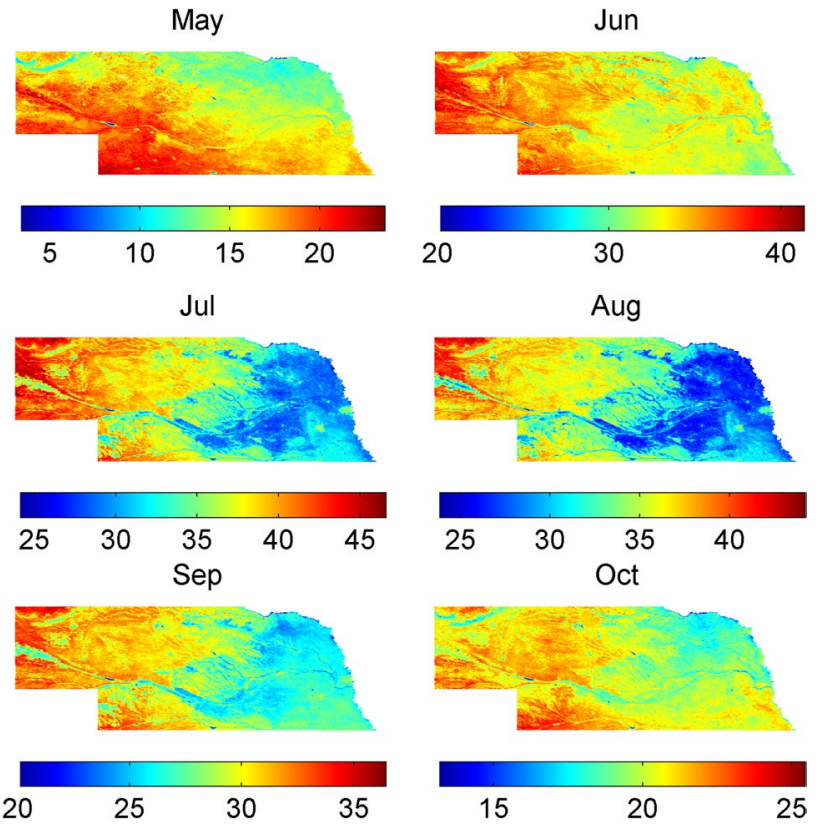

Fig. 5 MODIS satellite derived average monthly daytime surface temperatures $\left({ }^{\circ} \mathrm{C}\right)$ for $2000-2009$ in Nebraska. The significantly colder surface of irrigated land is noticeable even in October. Other months not displayed suffer from significant cloud contamination

is strong $(p=0.002)$, and while the least irrigated counties gained about $1 \mathrm{~mm}$ decade $^{-1}$ rain in the autumn (probably the result of the most significant seasonal air temperature increase of about $2{ }^{\circ} \mathrm{C}$ within the year), the most irrigated ones lost around $-5 \mathrm{~mm}$ decade $^{-1}$. Mainly because of this precipitation loss (by autumn irrigation completely ceases), ET from the most irrigated counties dropped a bit (reflected also in $T_{\mathrm{d}}$ increases smaller than those observed over least irrigated counties), while in counties with increasing rain, ET remained practically unchanged.

In the wintertime, none of the variables in general depend on irrigation development because of the low temperatures. The most significant precipitation response $\left(p=1.2 \times 10^{-8}\right)$ to irrigation in the spring, however, requires some additional explanation, as on a seasonal level, there is no clear corresponding response in the ET, $T_{\mathrm{a}}$, or $T_{\mathrm{d}}$ values.

In the spring, the largest precipitation decline $\left(p=5.6 \times 10^{-11}\right)$ to irrigation development takes place in March (Fig. 6) with all changes in the variables also statistically significant. As seen, March experienced a substantial increase in temperature (in excess of $3{ }^{\circ} \mathrm{C}$ with no irrigation), moderated by irrigation development. One may wonder how is it possible that large-scale irrigation which takes place entirely in the warm months (typically May, June, and July) could have a lasting effect even in March not only on air temperature, but simultaneously on air humidity and ET. Is it possible that the upper soil layers of the irrigated land would still contain more moisture than non-irrigated

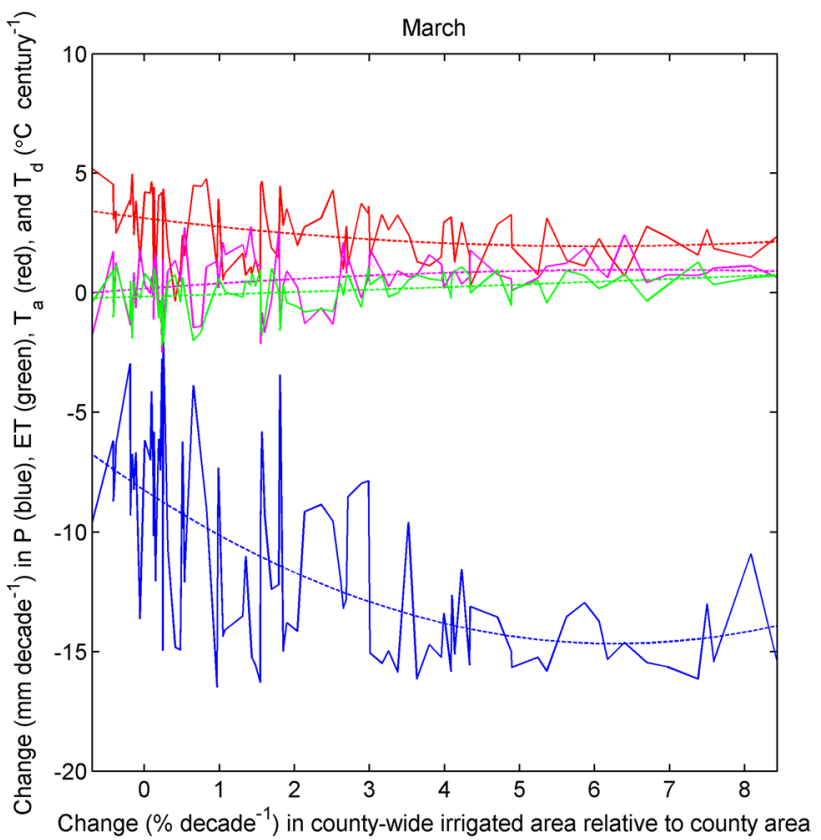

Fig. 6 Changes (1979-2015) in monthly precipitation $(P)$, ET, and air- $\left(T_{\mathrm{a}}\right)$ and dew-point temperature $\left(T_{\mathrm{d}}\right)$ values versus change in county-level irrigated land area in Nebraska. The intermittent lines are the best-fit second-order polynomials. The differences in the mean of the variables for the first (smallest or negative change in irrigated area) and last (largest expansion in irrigation) 30 counties are all statistically significant at the $5 \%$ level

land, especially after a long-term warming trend in autumn? The answer is clearly yes, because the warmer winters in Nebraska became also more humid (Fig. 4) due to increases in winter precipitation and thus making it possible to replenish soil moisture lost in the also warmer fall period from the upper layers of the soil essentially in the form of soil evaporation as crop water use by that time is significantly reduced (Kranz et al. 2008). Figure 7 demonstrates that irrigated land of typically maize and soybean in Nebraska attains a higher moisture status in the top layer of the soil in March than non-irrigated land, at least 10 out of the 11 years available.

\section{Conclusions}

PRISM observations of monthly precipitation, and air- and dew-point temperature, as well as complementary relationship-derived ET rates reveal how significantly large-scale irrigation development alters its atmospheric environment via not only reduced precipitation and air temperature, but also via elevated dew-point temperatures, and ET and ET ratios. Somewhat surprisingly, the largest precipitation suppression took place not in the summer but in the spring and fall periods due to counteracting forces of moisture-boosted convective available potential energy and surface-cooling 


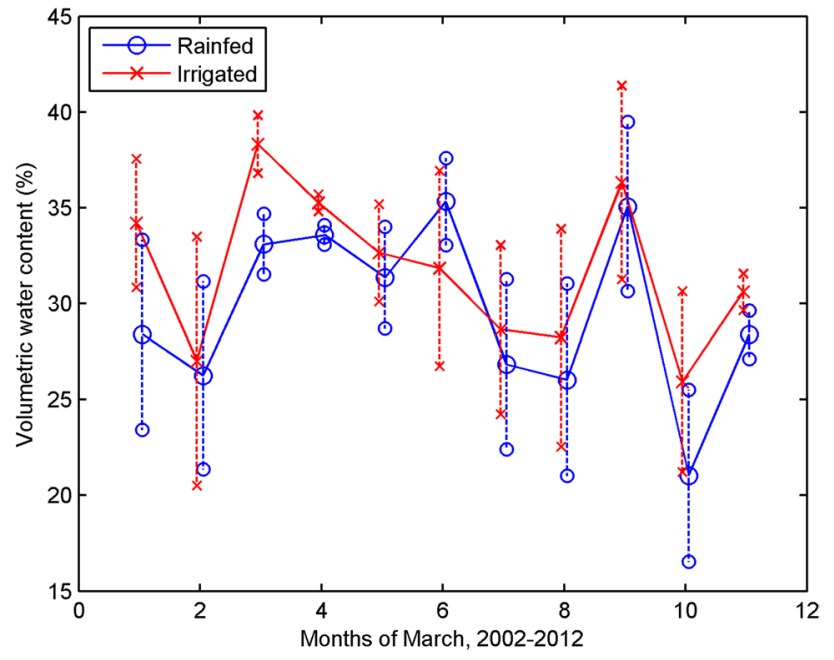

Fig. 7 Mean monthly volumetric water content of the soil averaged from three locations, $10 \mathrm{~cm}$ below the surface in March for irrigated and non-irrigated (rain-fed) maize-soybean plots between 2002 and 2012 in Mead, Nebraska (see Fig. 1 for location). The whiskers denote the standard deviations of the daily values in each month. Data source: https://ameriflux.lbl.gov/

activated inhibition of vertical convections (Harding and Snyder 2012). The latter seems to become predominant when the atmosphere is more stable, i.e., in spring and fall, leading to significant precipitation suppression in those seasons. It is important to stress again that spatial scale is a key factor in this latter process, because it occurs only over the largest virtually continuous irrigated area of east-central Nebraska. Counties at the narrowing western or northern flanks of the irrigated region (e.g., the northern most county with a red color and the one in pink around the middle of the top panel of Fig. 2) did not suffer any precipitation loss, even though they already had significant portions of irrigated land in 1979 that were also increasing at a fast rate afterwards. This is so because any flow pattern, such as described by Alter et al. (2015) that may develop over the irrigated cooler surface and is necessary for precipitation suppression, can withstand and modify the prevailing wind patterns only if its base is substantial in areal extent.

Figure 3 clearly demonstrates the statistically significant relationships that exist between the change/degree of irrigation development and the environmental variables studied. It yields strong support for the existence of a feedback mechanism between expansion of extensive areas of intensive irrigation and long-term precipitation decline that was first identified from measurements for the US by Szilagyi (2018a), and here was found somewhat more complex than it is typically explained (e.g., Alter et al. 2015) in the hydrologic literature. It is hoped that the current new findings will help with improved modeling of the atmospheric processes and enable us to better understand the linkages that exist between land-use change, the resultant mass and energy fluxes, and their complex effect on the regional and global climate. The current finding of an about $50 \mathrm{~mm}$ drop in local annual precipitation sums over a 3 -decade long period is in line with previous observations by Alter et al. (2015) in Africa and modeling results of Zeng et al. (2017) in India (despite the obvious climatic differences) about the extent of expected precipitation suppression over fast expanding intensive large-scale irrigation developments. This reduction in precipitation rates (i.e., about $-1.6 \mathrm{~mm} \mathrm{year}^{-1}$ ) maybe/is significant enough to be included in long-term sustainability studies and planning of water resources for large-scale irrigation developments.

Acknowledgements Open access funding provided by Budapest University of Technology and Economics (BME). All data used in this study are publicly available from the following sites: http://www. prism.oregonstate.edu (PRISM data), https://earlywarning.usgs.gov/ USirrigation (MIrAD irrigation data), https://modis.gsfc.nasa.gov/ data/ (surface temperature data), and https://ameriflux.lbl.gov/ (soil moisture data). Spatially distributed ET data of this study are available from https://digitalcommons.unl.edu/natrespapers/986/. The authors are grateful to the two anonymous reviewers whose comments led to important changes. Special thanks to Andy Suyker for his help with the Mead, NE soil moisture data. The research reported in this paper was supported by the BME-Water Sciences and Disaster Prevention FIKP Grant of EMMI (BME FIKP-VÍZ).

Open Access This article is licensed under a Creative Commons Attribution 4.0 International License, which permits use, sharing, adaptation, distribution and reproduction in any medium or format, as long as you give appropriate credit to the original author(s) and the source, provide a link to the Creative Commons licence, and indicate if changes were made. The images or other third party material in this article are included in the article's Creative Commons licence, unless indicated otherwise in a credit line to the material. If material is not included in the article's Creative Commons licence and your intended use is not permitted by statutory regulation or exceeds the permitted use, you will need to obtain permission directly from the copyright holder. To view a copy of this licence, visit http://creativecommons.org/licenses/by/4.0/.

\section{References}

Alter RE, Im E-S, Eltahir EAB (2015) Rainfall consistently enhanced around the Gezira Scheme in East Africa due to irrigation. Nat Geosci 8:763-767. https://doi.org/10.1038/ngeo2514

Best MJ et al (2015) The plumbing of land surface models: benchmarking model performance. J Hydrometeorol 16(3):1425-1442. https ://doi.org/10.1175/jhm-d-14-0158.1

Brown JF, Pervez MS (2014) Merging remote sensing data and national agricultural statistics to model change in irrigated agriculture. Agric Syst 127:28-40. https://doi.org/10.1016/j.agsy.2014.01.004

Daly C, Neilson RP, Phillip DL (1994) A statistical topographic model for mapping climatological precipitation over mountainous terrain. J Appl Meteorol 33:140-158

DeAngelis A, Dominguez F, Fan Y et al (2010) Evidence of enhanced precipitation due to irrigation over the Great Plains of the United States. J Geophys Res 115:D15115. https://doi.org/10.1029/2010J D013892 
Food and Agricultural Organization of the United Nations (2016) AQUASTAT website. http://www.fao.org/nr/water/aquastat/didyo uknow/index3.stm. Accessed 29 July 2019

Gleick PH (2003) Water use. Annu Rev Environ Resour 28:275-314

Hamed KH, Rao AR (1998) A modified Mann-Kendall trend test for autocorrelated data. J Hydrol 204:182-196

Hanak E, Lund J, Dinar A et al (2011) Managing California's water: from conflict to reconciliation. Public Policy Institute of California, San Francisco

Harding KJ, Snyder PK (2012) Modeling the atmospheric response to irrigation in the Great Plains. Part II: the precipitation of irrigated water and changes in precipitation recycling. J Hydrometeorol 13:1687-1703. https://doi.org/10.1175/JHM-D-11-099.1

Huber DB, Mechem DB, Brunsell NA (2014) The effects of Great Plains irrigation on the surface energy balance, regional circulation, and precipitation. Climate 2:103-108. https://doi. org/10.3390/cli2020103

Johnson B, Thompson C, Giri A et al (2011) Nebraska irrigation fact sheet. Dept. Agricult. Econom Report\# 190, University of Nebraska-Lincoln, Lincoln

Kranz WL, Irmak S, vanDonk SJ et al (2008) Irrigation management for corn. NebGuide G1850, University of Nebraska-Lincoln Extension

Kustu MD, Fan Y, Rodell M (2011) Possible link between irrigation in the US High Plains and increased summer streamflow in the Midwest. Water Resour Res 47(3):W03522. https://doi. org/10.1029/2010WR010046

Mahmood R et al (2010) Impact of land use/land cover change on climate and future research priorities. Bull Am Meteorol Soc 91:37-46. https://doi.org/10.1175/2009BAMS2769.1

Mahmood R et al (2014) Land cover changes and their biophysical effects on climate. Int J Climatol 34:929-953

Mesinger $F$ et al (2006) North American regional reanalysis. Bull Am Meteorol Soc 87:343-360. https://doi.org/10.1175/ BAMS-87-3-343

Nebraska Department of Agriculture (2019) Nebraska Agricultural Fact Card. USDA NASS, Lincoln
Pei L, Moore N, Zhong S, Kendall AD, Gao Z, Hyndman DW (2016) Effects of irrigation on summer precipitation over the United States. J Clim 29:3541-3558. https://doi.org/10.1175/ JCLI-D-15-0337.1

Pielke RA et al (2011) Land use/land cover changes and climate: modeling analysis and observational evidence. WIREs Clim Change 2:828-850. https://doi.org/10.1002/wcc. 144

Puma MJ, Cook BI (2010) Effects of irrigation on global climate during the 20th century. J Geophys Res 115:D16120

Szilagyi J (2018a) Anthropogenic hydrological cycle disturbance at a regional scale: state-wide evapotranspiration trends (19792015) across Nebraska, USA. J Hydrol 557:600-612. https://doi. org/10.1016/j.jhydrol.2017.12.062

Szilagyi J (2018b) A calibration-free, robust estimation of monthly land surface evapo-transpiration rates for continental-scale hydrology. Hydrol Res 49(3):648-657. https://doi.org/10.2166/nh.2017.078

Szilagyi J, Crago R, Qualls RJ (2017) A calibration-free formulation of the complementary relationship of evaporation for continentalscale hydrology. J Geophys Res Atmos 122(1):264-278. https:// doi.org/10.1002/2016JD025611

United States Department of Agriculture (2012) Census of agriculture. https://www.agcensus.usda.gov/Publications/2012/. Accessed 3 June 2018

Verma SB, Dobermann A, Cassman KG et al (2005) Annual carbon dioxide exchange in irrigated and rainfed maize-based agroecosystems. Agric For Meteorol 131:77-96

Waehler TA, Dietrichs ES (2017) The vanishing Aral Sea: health consequences of an environmental disaster. Tidsskr Nor Legeforen. https://doi.org/10.4045/tidsskr.17.0597

Wei J, Dirmeyer PA, Wisser D et al (2013) Where does the irrigation water go? An estimate of the contribution of irrigation to precipitation using MERRA. J Hydrometeorol 14:275-289

Zeng Y, Xie Z, Zou J (2017) Hydrologic and climatic responses to global anthropogenic groundwater extraction. J Clim 30(1):71-90

Publisher's Note Springer Nature remains neutral with regard to jurisdictional claims in published maps and institutional affiliations. 